\title{
Minimizing Oxidation of Freeze-Dried Monoclonal Antibodies in Polymeric Vials Using a Smart Packaging Approach
}

\author{
Nicole Härdter ${ }^{1}$, Tim Menzen ${ }^{2}\left(\mathbb{D}\right.$ and Gerhard Winter ${ }^{1, *}$ \\ 1 Department of Pharmacy, Pharmaceutical Technology and Biopharmaceutics, \\ Ludwig-Maximilians-Universität München, 81377 Munich, Germany; nicole.haerdter@cup.uni-muenchen.de \\ 2 Coriolis Pharma, Fraunhoferstr. 18 b, 82152 Munich, Germany; tim.menzen@coriolis-pharma.com \\ * Correspondence: gerhard.winter@cup.uni-muenchen.de
}

check for updates

Citation: Härdter, N.; Menzen, T.; Winter, G. Minimizing Oxidation of Freeze-Dried Monoclonal Antibodies in Polymeric Vials Using a Smart Packaging Approach. Pharmaceutics 2021, 13, 1695. https://doi.org/ 10.3390/pharmaceutics13101695

Academic Editor: Anna Angela Barba

Received: 20 August 2021

Accepted: 28 September 2021

Published: 15 October 2021

Publisher's Note: MDPI stays neutral with regard to jurisdictional claims in published maps and institutional affiliations.

Copyright: (c) 2021 by the authors. Licensee MDPI, Basel, Switzerland. This article is an open access article distributed under the terms and conditions of the Creative Commons Attribution (CC BY) license (https:// creativecommons.org/licenses/by/ $4.0 /)$.

\begin{abstract}
Primary containers made of cyclic olefin polymer (COP) have recently gained attention since they may overcome several risks and shortcomings of glass containers as they exhibit a high break resistance, biocompatibility, and homogeneous heat transfer during lyophilization. On the downside, COP is more permeable for gases, which can lead to an ingress of oxygen into the container over time. Since oxidation is an important degradation pathway for monoclonal antibodies (mAbs), the continuous migration of oxygen into drug product containers should be avoided overall. To date, no long-term stability studies regarding lyophilizates in polymer vials have been published, potentially because of the unbearable gas permeability. In this study, we demonstrate that after lyophilization in COP vials and storage of these vials in aluminum pouches together with combined oxygen and moisture absorbers ("smart packaging"), oxidation of two lyophilized therapeutic antibodies was as low as in glass vials due to the deoxygenated environment in the pouch. Nevertheless, active removal of oxygen from the primary container below the initial level over time during storage in such "smart" secondary packaging was not achieved. Furthermore, residual moisture was controlled. Overall, the smart packaging reveals a promising approach for long-term stability of biopharmaceuticals; in addition to COP's known benefits, stable, low oxygen and moisture levels as well as the protection from light and cushioning against mechanical shock by the secondary packaging preserve the sensitive products very well.
\end{abstract}

Keywords: COP; polymer; absorber; freeze-drying; lyophilization; oxidation; oxygen permeation; monoclonal antibody; stability

\section{Introduction}

Monoclonal antibodies (mAbs) are therapeutically highly relevant drugs [1]. Due to the complex structure of these molecules, chemical and physical degradation is frequently observed and therefore formulation of stable liquid dosage forms may be challenging [2-4]. Freeze-drying is a frequently employed technique to provide sufficient shelf life and improved stability during shipping for labile protein drugs [5,6]. Vials made of glass are the most common primary packaging for freeze-dried pharmaceuticals [7] due to the materials' inertness, transparency and excellent barrier properties against moisture and gases [8,9]. Nevertheless, concerns with glass like ion leaching, delamination and its susceptibility regarding breakage can affect safety and efficacy $[7,10]$ and thus may lead to recalls [11]. More recently, vials made of cyclic olefin polymers and copolymers (COP and $\mathrm{COC}$ ) have attracted attention as they have overcome the major drawbacks of glass by showing excellent chemical resistance [9] and low adsorption [7,12,13], while likewise providing a translucent and inert surface [7]. Moreover, an obvious benefit over glass is the great break resistance of the polymers, which therefore makes them favorable for recent cell and gene therapies as well [10,14-16]. Moreover, an environmental benefit using polymer over glass vials was found [17]. For more detailed information on plastic packaging, the reader is referred elsewhere [9]. 
It has been shown previously that lyophilization in cyclic olefins results in homogeneous heat transfer [18] and increased uniformity within the cakes [9]. The major disadvantage of these polymeric materials is their permeability to gases, e.g., oxygen and water vapor [10], and therefore shelf life might be jeopardized. Particularly when it comes to biopharmaceuticals, which are prone to oxidation, contact with oxygen needs to be eliminated during storage. Since oxygen is constantly available in the ambient air, it can either damage biopharmaceuticals by directly oxidizing susceptible amino acids (e.g., methionine, cysteine) or by generating reactive oxygen species (ROS) [9]. Protein oxidation is one of the major degradation pathways and can lead to detrimental biological consequences, i.e., loss of potency, altered pharmacokinetics as well as unwanted immunogenicity [19-21]. Thus, vials are sealed under nitrogen atmosphere at the end of a lyophilization cycle. Moreover, residual moisture content of the lyophilizates throughout storage has to be taken into account, as it may directly deteriorate long-term stability of proteins as a potential reactant or by increasing molecular mobility as a plasticizer [22,23]. Hence, penetration of water vapor through the container walls of COP vials would increase the residual moisture of the lyophilized product and consequently result in reduced glass transition temperatures, eventually leading to a collapse of the cake [24].

To provide the necessary barrier function for cyclic olefin polymers, secondary packaging such as aluminum pouches may be utilized. This concept has already been introduced for packaging of biotech products in prefilled polymer syringes and has reached the market, e.g., in Japan, several years ago. Previous studies showed for liquid formulations that protein oxidation in COP syringes can be successfully suppressed when the syringes were stored in a blister pack containing an oxygen absorber $[25,26]$. Similarly, another approach investigated by Werner et al. prevented oxidation of therapeutic proteins by storage of COP syringes in nitrogen-filled aluminum pouches [27]. So far, lyophilizates in COP vials have not really been thought of as a relevant configuration, and the use of absorbers as enabling tools has not been considered in this context.

For the first time, in this study we evaluated the suitability of smart secondary packaging, including combined oxygen and moisture absorbers in aluminum pouches for lyophilizates of two relevant therapeutic monoclonal antibodies in COP vials. Oxygen levels in the headspaces, residual moisture of the lyophilizates as well as the chemical and physical stability of the mAbs were investigated at three different storage temperatures over the course of up to 12 months.

\section{Materials and Methods}

\subsection{Monoclonal Antibodies and Chemicals}

Two monoclonal IgG type 1 antibodies (mAbs) named LMU1 and LMU2 in the following were used in this study. The investigated model mAbs were selected because of their potential susceptibility to oxidation. L-histidine monohydrochloride monohydrate ( $99 \%$ purity) and L-histidine (cell culture reagent) were purchased from Alfa Aesar (Ward Hill, MA, USA). D(+)-trehalose dihydrate (97.0-102.0\% purity) Ph. Eur., NF certified was purchased from VWR International (Radnor, PA, USA). EMPROVE ${ }^{\circledR}$ exp sucrose, EMPROVE $^{\circledR}$ bio sodium chloride, EMSURE ${ }^{\circledR}$ sodium dihydrogen phosphate monohydrate, EMSURE ${ }^{\circledR}$ potassium dihydrogen phosphate, and EMSURE ${ }^{\circledR}$ sodium hydroxide solution $50 \%$ were purchased from Merck KGaA (Darmstadt, Germany). TWEEN ${ }^{\circledR} 20 \mathrm{Ph}$. Eur. certified, ammonium sulfate of BioXtra grade and acetic acid ( $\geq 99.8 \%$ purity) Ph. Eur. certified were purchased from Sigma-Aldrich (Steinheim, Germany). Super Refined ${ }^{\mathrm{TM}}$ Polysorbate 80-LQ-(MH) was purchased from Croda (Edison, NJ, USA). Di-sodium hydrogen phosphate dihydrate and potassium chloride were purchased from AppliChem $\mathrm{GmbH}$ (Darmstadt, Germany). For the preparation of all solutions, ultrapure water from an Arium ${ }^{\circledR}$ system of Sartorius Lab Instruments GmbH (Goettingen, Germany) was used. 


\subsection{Preparation of the Formulations}

The bulk solutions of both mAbs were buffer exchanged to $20 \mathrm{mM}$ (LMU1) or $10 \mathrm{mM}$ (LMU2) histidine/histidine hydrochloride with pH 5.5 at $20{ }^{\circ} \mathrm{C}$ to $25{ }^{\circ} \mathrm{C}$ using SlideA-Lyzer ${ }^{\mathrm{TM}}$ 10,000 molecular weight cut-off dialysis cassettes (Thermo Fisher Scientific, Waltham, MA, USA). After extensive dialysis as described by Svilenov et al. [28], the final buffers contained either $20 \mathrm{mM}$ histidine and $0.04 \%(w / v)$ polysorbate 20 for LMU1 or $10 \mathrm{mM}$ histidine and $0.05 \%(w / v)$ polysorbate 80 for LMU2. The concentration of both antibodies was measured with a Nanodrop 2000 UV spectrophotometer (Thermo Fisher Scientific, Waltham, MA, USA). Stock solutions of the excipients were prepared in the respective histidine buffer and mixed with the dialyzed protein solution in a way that the final formulation contained $10 \mathrm{~g} / \mathrm{L} \mathrm{mAb}$ and either $7.2 \%$ trehalose and $0.04 \%(w / v)$ polysorbate 20 (LMU1) or $10 \%$ sucrose and $0.05 \%(w / v)$ polysorbate $80($ LMU2). Both formulations were sterile filtered using a $0.22 \mu \mathrm{m}$ Sartolab ${ }^{\circledR} \mathrm{RF}$ polyethersulfone vacuum filtration unit (Sartorius AG, Goettingen, Germany) prior to filling into the vials. Then, for each formulation, $2.5 \mathrm{~mL}$ were filled in $6 \mathrm{R}$ tubing vials either made from cyclic olefin polymer (COP Monolayer, Gerresheimer AG, Duesseldorf, Germany) or glass (Schott AG, Mainz, Germany) and semi-stoppered with lyophilization stoppers (Flurote ${ }^{\circledR}$ laminated rubber stoppers, West Pharmaceutical Services, Inc, Exton, PA, USA). The vials were arranged on a tray and surrounded by one row of shielding vials containing the respective placebo.

\subsection{Freeze-Drying Process}

Lyophilization was conducted using an FTS LyoStar ${ }^{\text {TM }} 3$ freeze-dryer (SP Scientific, Stone Ridge, NY, USA) following the same protocol for both formulations. Freezing was carried out as suggested by Tang et al. [5] with a few changes; once the shelf temperature $\left(\mathrm{T}_{\mathrm{s}}\right)$ reached $5{ }^{\circ} \mathrm{C}$ and $-5^{\circ} \mathrm{C}$ subsequently, the respective temperatures were held for $45 \mathrm{~min}$. The final freezing shelf temperature of $-50{ }^{\circ} \mathrm{C}$ was held for $3 \mathrm{~h}$. All cooling rates were $1 \mathrm{~K} / \mathrm{min}$. Primary drying was conducted at a shelf temperature of $-20^{\circ} \mathrm{C}$ (ramp $1 \mathrm{~K} / \mathrm{min}$ ) and a pressure of $90 \mu \mathrm{bar}$. The end of primary drying was determined by comparative pressure measurement between the thermal conductivity pressure gauge (Pirani) and the capacitance pressure gauge (MKS). $\mathrm{T}_{\mathrm{s}}$ was then increased to $5^{\circ} \mathrm{C}$ (ramp $0.15 \mathrm{~K} / \mathrm{min}$ ) and further to $30^{\circ} \mathrm{C}(\mathrm{ramp} 0.21 \mathrm{~K} / \mathrm{min}$ ) for secondary drying and held for $7 \mathrm{~h}$ at the aforementioned chamber pressure. After completion of the lyophilization cycle, the vials were stoppered under nitrogen atmosphere at 600 mbar and crimped with Flip-Off ${ }^{\circledR}$ seals (West Pharmaceutical Services, Inc, Exton, PA, USA).

\subsection{Study Design}

Subsequent to lyophilization, the vials were stored in three configurations as follows: configuration 1 (COP $-\mathrm{A}-\mathrm{P})$, $\mathrm{COP}$ vials stored without further secondary packaging; configuration $2(\mathrm{COP}+\mathrm{A}+\mathrm{P})$, according to Figure 1 each $\mathrm{COP}$ vial was single packed in an aluminum pouch (Floeter Verpackungsservice, Eberdingen, Germany) with one combined oxygen and moisture absorber (Pharmakeep ${ }^{\circledR}$, Mitsubishi Gas Chemicals, Tokyo, Japan), where " $\mathrm{A}$ " stands for the absorber and the aluminum pouches are abbreviated " $\mathrm{P}$ " for more convenient reading, respectively. Sealing of the aluminum pouches was done at ambient conditions using a Polystar 245 (Rische + Herfurth GmbH, Hamburg, Germany). Furthermore, configuration 3 (glass) consisted of glass vials stored without secondary packaging. Samples from each configuration were stored under the exclusion of light at $4{ }^{\circ} \mathrm{C}, 25^{\circ} \mathrm{C}$ and $40^{\circ} \mathrm{C}$ for the desired time without controlling the relative humidity.

\subsection{Oxygen Quantification}

The oxygen concentration in the aluminum pouches and in the headspaces of the lyophilizates was measured by using a Microx 4 fiber optic oxygen meter (PreSens Precision Sensing GmbH, Regensburg, Germany). For the lyophilizates, the cap of the Flip-Off ${ }^{\circledR}$ seal was removed, and the needle-shielded sensor was introduced into the headspace by piercing the rubber stopper. 


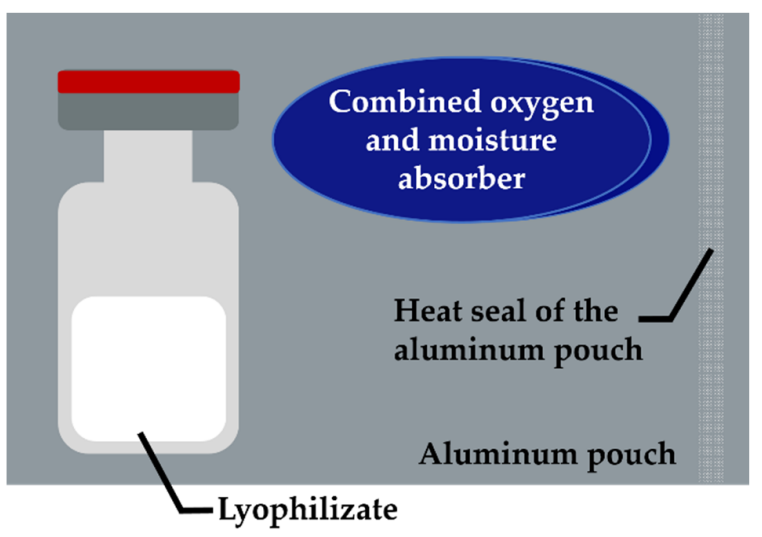

Figure 1. Illustration of the smart packaging system with combined oxygen and moisture absorber. Each pouch was equipped with one absorber and one vial containing the lyophilizate and heat sealed under ambient conditions.

\subsection{Karl-Fischer Titration}

To determine the residual moisture content of the lyophilizates, coulometric Karl Fischer titration was used. The cakes were gently crushed under controlled humidity conditions in a glove box filled with pressurized air (relative humidity $<10 \%$ ), and $30-50 \mathrm{mg}$ of each cake was transferred into $2 \mathrm{R}$ vials and stoppered. Subsequently, the samples were placed in an oven (temperature $100^{\circ} \mathrm{C}$ ), and the extracted water was transferred to the coulometric titration cell with a dry carrier gas flow (Aqua 40.00 Vario plus, ECH Elektrochemie Halle $\mathrm{GmbH}$, Halle (Saale), Germany). Knowing the weight of the sample, relative moisture content was calculated $(w / w)$. Prior to analysis of the samples, equipment performance was verified by measuring the Apura ${ }^{\circledR}$ water standard oven $1 \%$ (Merck KGaA, Darmstadt, Germany) in triplicate.

\subsection{Reconstitution of the Lyophilizates}

Reconstitution of the lyophilized cakes was done by the addition of ultrapure water. For both formulations, the required volume was calculated to correspond to the volume of water removed during freeze-drying.

\subsection{Hydrophobic Interaction Chromatography}

The separation of oxidized species of LMU1 was performed on a Thermo Scientific ${ }^{\mathrm{TM}}$ Dionex $^{\mathrm{TM}}$ UltiMate $^{\mathrm{TM}} 3000$ UHPLC system equipped with a VWD-3400RS UV/Vis absorbance detector using a MabPac HIC-20 column $(4.6 \times 250 \mathrm{~mm})$, all from Thermo Fisher Scientific (Waltham, MA, USA). According to Baek et al. [29] the mobile phase A contained $2 \mathrm{M}$ ammonium sulfate and $100 \mathrm{mM}$ sodium phosphate, $\mathrm{pH} 7.0$, whereas mobile phase B solely consisted of $100 \mathrm{mM}$ sodium phosphate, $\mathrm{pH}$ 7.0. Prior to analysis, the samples were diluted to a $\mathrm{mAb}$ concentration of $5 \mathrm{~g} / \mathrm{L}$ with mobile phase $\mathrm{A}$, and $5 \mu \mathrm{L}$ were injected. Starting with $60 \% \mathrm{~B}$ at a flow rate of $0.5 \mathrm{~mL} / \mathrm{min}$ for $2 \mathrm{~min}$, a linear gradient from $60 \%$ to $100 \%$ B in 28 min was then performed to separate the oxidation variants of LMU1. The elution of the samples was detected by absorption at $280 \mathrm{~nm}$. The chromatograms were integrated using Chromeleon ${ }^{\mathrm{TM}}$ 7.2.7 (Thermo Fisher Scientific, Waltham, MA, USA). Because of the different extinction coefficients of the oxidized species, we used Equation (1) for the determination of the amount of fully oxidized $\mathrm{mAb}$, adapted from Reference [30]:

$$
\% \text { Fully oxidized } \mathrm{mAb}=100 \times \frac{\text { Area }_{\text {oxidized }}}{\left(\text { Area }_{\text {oxidized }}+\frac{\text { Area }_{\text {initial }}}{\mathrm{RF}_{\mathrm{I} / \mathrm{O}}}\right)}
$$

$\mathrm{RF}_{\mathrm{I} / \mathrm{O}} \mathrm{UV} 280 \mathrm{~nm}: 1.49$. For the calibration data see Figure $\mathrm{S} 1$ in the Supplementary Materials. 


\subsection{Protein A Chromatography}

For the separation of oxidized species of LMU2, we used a Thermo Scientific ${ }^{\mathrm{TM}}$ Dionex $^{\mathrm{TM}}$ UltiMate $^{\mathrm{TM}} 3000$ UHPLC system equipped with a VWD-3400RS UV/Vis absorbance detector and a POROS ${ }^{\circledR}$ A column $(20 \mu \mathrm{m}, 4.6 \times 50 \mathrm{~mm})$, all from Thermo Fisher Scientific (Waltham, MA, USA). The suitability of analytical protein A chromatography for the quantitative detection of oxidation was demonstrated by Loew et al. [31] more recently. Mobile phase A consisted of $10 \mathrm{mM}$ phosphate-buffered saline with $2.7 \mathrm{mM}$ potassium chloride and $134 \mathrm{mM}$ sodium chloride, $\mathrm{pH}$ 7.4, whereas mobile phase B contained $100 \mathrm{mM}$ acetic acid and $150 \mathrm{mM}$ sodium chloride at $\mathrm{pH} 2.8$. After an adsorption period of $5 \mathrm{~min}$ with $0 \% \mathrm{~B}$ at a flow rate of $2 \mathrm{~mL} / \mathrm{min}$, elution was performed in a linear gradient mode from $0 \%$ B to $36 \%$ B in $24 \mathrm{~min}$. The injection volume was $10 \mu \mathrm{L}$. The elution of the samples was detected at $280 \mathrm{~nm}$, and subsequently, the chromatograms were integrated using Chromeleon $^{\mathrm{TM}}$ 7.2.7 (Thermo Fisher Scientific, Waltham, MA, USA). As for LMU1, the amount of fully oxidized $\mathrm{mAb}$ was determined with Equation (1), however using the main peak heights instead of the peak areas ( $\mathrm{RF}_{\mathrm{I} / \mathrm{O}} \mathrm{UV} 280 \mathrm{~nm}$ : 0.68). For the calibration data see Figure S2 in the Supplementary Materials.

\subsection{Flow Imaging Microscopy}

The formation of subvisible particles during storage in the different packaging configurations was analyzed with a FlowCam 8100 (Fluid Imaging Technologies, Inc., Scarborough, ME, USA) for both $\mathrm{mAbs}$. The system was equipped with a $10 \times$ magnification flow cell $(80 \mu \mathrm{m} \times 700 \mu \mathrm{m})$ and controlled by the VisualSpreadsheet ${ }^{\circledR} 4.7 .6$ software. At a flow rate of $0.15 \mathrm{~mL} / \mathrm{min}, 150 \mu \mathrm{L}$ sample was analyzed, and particle images were obtained at an auto image frame rate of 28 frames/s. The settings for particle identifications were $3 \mu \mathrm{m}$ distance to the nearest neighbor and particle thresholds of 13 and 10 for dark and light pixels, respectively. The particle size was evaluated as the equivalent spherical diameter.

\section{Results}

\subsection{Effect of the Absorber on the Oxygen Levels in the Pouches}

We sealed the pouches for the smart packaging at ambient conditions to investigate the performance of the absorbers in a worst-case scenario. Within four weeks of storage, the oxygen levels in the pouches were strongly reduced from $20.1 \%$ right after sealing to less than $0.3 \%$ oxygen for both $\mathrm{mAb}$ formulations irrespective of the storage temperature (Figure 2). Moreover, longer observations over the course of 3 months at elevated temperatures, i.e., $25^{\circ} \mathrm{C}$ and $40^{\circ} \mathrm{C}$ and over 12 months at $4{ }^{\circ} \mathrm{C}$ storage temperature revealed that the aforementioned reduction was long-lasting, since the oxygen levels remained below $0.3 \%$.

\subsection{Effect of the Absorber on the Oxygen Levels in the Headspaces of the Lyophilizates}

After lyophilization, oxygen levels in the headspaces were $6.73 \% \pm 0.05 \%$ (COP) and $6.43 \% \pm 0.08 \%$ (glass). If not depleted by an absorber, oxygen permeated into the COP vials from the oxygen-rich surrounding air (Figure $3, \mathrm{COP}-\mathrm{A}-\mathrm{P}$ ). The longer the time a $\mathrm{COP}$ vial was exposed to ambient air and the higher the storage temperature, the more oxygen was found in the headspace. After 12 months at $4{ }^{\circ} \mathrm{C}$, the oxygen level in the headspace of $\mathrm{COP}-\mathrm{A}-\mathrm{P}$ almost evened the atmospheric concentration with $17.3 \% \pm 0.31 \%$ oxygen (Figure 3A). Under accelerated storage conditions at elevated temperatures (Figure 3B), we determined a quick increase in headspace oxygen within 1 month, which further ramped up to $13.80 \% \pm 0.50 \%$ for LMU1 and $13.43 \% \pm 0.93 \%$ for LMU2 at $25^{\circ} \mathrm{C}$. For the samples stored at $40{ }^{\circ} \mathrm{C}$ (Figure 3C), the initial increase of oxygen in the headspace of COP - A $-\mathrm{P}$ was somewhat more pronounced $(10.94 \% \pm 0.43 \%$ for LMU1, $10.13 \% \pm 0.28 \%$ for LMU2) over the course of 1 month. For LMU1, it then further increased to $15.80 \% \pm 0.34 \%$, while permeation was a little slower for LMU2, resulting in $11.53 \% \pm 0.06 \%$ oxygen after 3 months. 


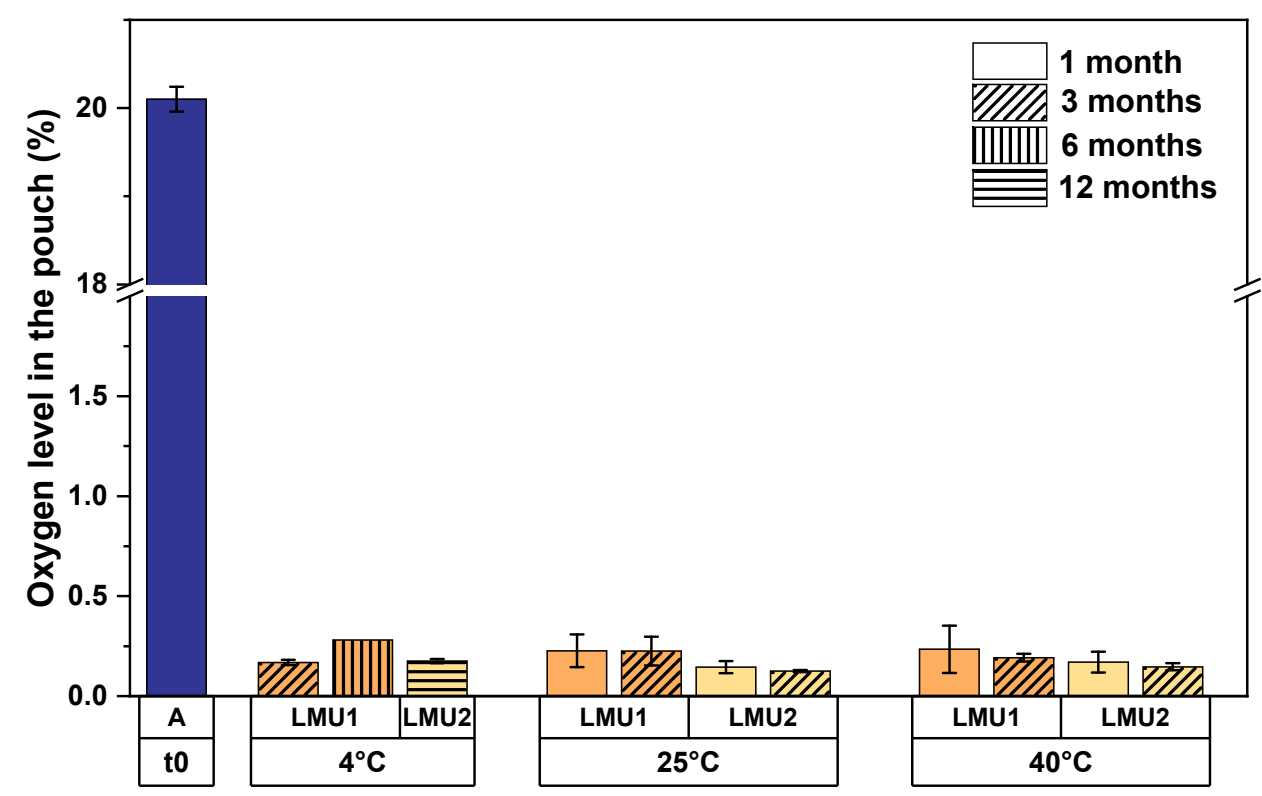

Figure 2. Oxygen levels in the aluminum pouches stored at different temperatures for the respective time. Sealing was done at ambient conditions with a mean oxygen concentration of $20.1 \%$ (blue). The bars are means of six individual pouches; the error bars represent the standard deviation. A, ambient.
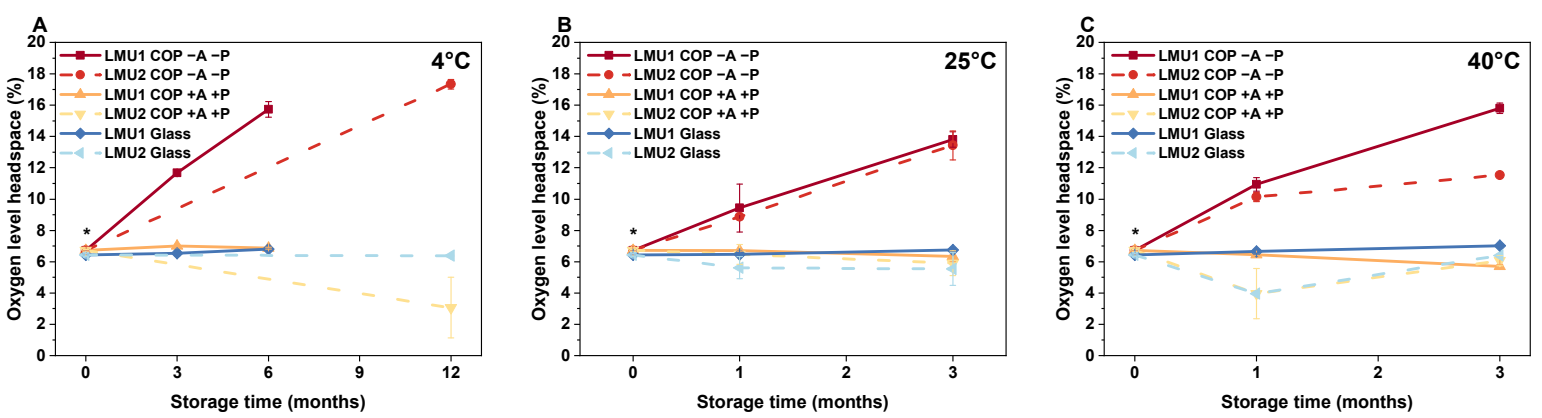

Figure 3. Oxygen levels in the headspaces of the lyophilizates containing LMU1 and LMU2 measured directly after freeze-drying and after storage up to 6 months (LMU1) and up to 12 months (LMU2) at $4{ }^{\circ} \mathrm{C}(\mathrm{A}), 25^{\circ} \mathrm{C}(\mathbf{B})$, and $40{ }^{\circ} \mathrm{C}$ (C). Asterisks ${ }^{*}$ ) represent repeated experiment for LMU2 because occasionally implausible initial data were obtained. The values are means ( $n=6$ for LMU1; $n=3$ for LMU2) \pm standard deviation. COP, cyclic olefin polymer; A, absorber; P, pouch.

For $\mathrm{COP}$ in the smart packaging $(\mathrm{COP}+\mathrm{A}+\mathrm{P})$, headspace oxygen levels remained low comparable to those seen in glass, irrespective of the formulation. We even saw a slight decrease in headspace oxygen over time according to the storage temperature. After 3 months, the headspace oxygen level for LMU1 in COP $+\mathrm{A}+\mathrm{P}$ at $4{ }^{\circ} \mathrm{C}$ was $6.87 \% \pm 0.06 \%$ (Figure $3 \mathrm{~A}$ ); at $25^{\circ} \mathrm{C}$, we found $6.35 \% \pm 0.33 \%$ (Figure $3 \mathrm{~B}$ ), and $5.70 \% \pm 0.11 \%$ oxygen at $40{ }^{\circ} \mathrm{C}$ (Figure $3 \mathrm{C}$ ), respectively. Moreover, we observed a time-dependent effect on headspace oxygen in the smart packaging as well. When we stored LMU2 in COP $+\mathrm{A}+\mathrm{P}$ at $4{ }^{\circ} \mathrm{C}$ (Figure $3 \mathrm{~A}$ ), the headspace oxygen level was significantly reduced to $3.07 \% \pm 1.93 \%$ after 12 months.

In the glass vials, headspace oxygen levels remained low for both formulations. Nevertheless, with increasing storage temperature, i.e., $25^{\circ} \mathrm{C}$ and $40^{\circ} \mathrm{C}$, we even saw a slight increase in headspace oxygen for LMU1 over time. At $25^{\circ} \mathrm{C}$ we found $6.75 \% \pm 0.14 \%$ (Figure $3 \mathrm{~B}$ ) and $7.02 \% \pm 0.13 \%$ (Figure $3 \mathrm{C}$ ) oxygen in the respective headspaces of LMU1 after 3 months. 


\subsection{Effect of the Absorber on Residual Moisture Content of the Lyophilizates}

After lyophilization, we observed slightly higher residual moisture contents in COP $(0.50 \% \pm 0.04 \%$ for LMU1, $1.17 \% \pm 0.05 \%$ for LMU2) compared to glass $(0.38 \% \pm 0.08 \%$ for LMU1, $1.03 \% \pm 0.07 \%$ for LMU2), as shown in Table 1.

Table 1. Residual moisture results of the lyophilizates stored at different temperatures for the respective time.

\begin{tabular}{|c|c|c|c|c|c|c|c|c|}
\hline \multicolumn{2}{|c|}{ Configuration } & \multicolumn{7}{|c|}{ Residual Moisture, \% } \\
\hline & & & \multicolumn{2}{|c|}{$4{ }^{\circ} \mathrm{C}$} & \multicolumn{2}{|c|}{$25^{\circ} \mathrm{C}$} & \multicolumn{2}{|c|}{$40^{\circ} \mathrm{C}$} \\
\hline & & $0 \mathrm{~m}$ & $3 \mathrm{~m}$ & $6 \mathrm{~m}$ & $1 \mathrm{~m}$ & $3 \mathrm{~m}$ & $1 \mathrm{~m}$ & $3 \mathrm{~m}$ \\
\hline \multirow{4}{*}{ LMU1 } & $\mathrm{COP}-\mathrm{A}-\mathrm{P}$ & $0.50 \pm 0.04$ & $0.88 \pm 0.04$ & $0.92 \pm 0.03$ & $0.68 \pm 0.00$ & $1.13 \pm 0.01$ & $0.68 \pm 0.02$ & $1.02 \pm 0.03$ \\
\hline & $\mathrm{COP}+\mathrm{A}+\mathrm{P}$ & $0.50 \pm 0.04$ & $0.78 \pm 0.04$ & $0.61 \pm 0.02$ & $0.57 \pm 0.02$ & $0.81 \pm 0.02$ & $0.66 \pm 0.01$ & $0.84 \pm 0.01$ \\
\hline & Glass & $0.38 \pm 0.08$ & $0.65 \pm 0.08$ & $0.47 \pm 0.03$ & $0.48 \pm 0.03$ & $0.68 \pm 0.02$ & $0.54 \pm 0.02$ & $0.60 \pm 0.06$ \\
\hline & & $0 \mathrm{~m}$ & \multicolumn{2}{|c|}{$12 \mathrm{~m}$} & $1 \mathrm{~m}$ & $3 \mathrm{~m}$ & $1 \mathrm{~m}$ & $3 \mathrm{~m}$ \\
\hline \multirow{3}{*}{ LMU2 } & $\mathrm{COP}-\mathrm{A}-\mathrm{P}$ & $1.17 \pm 0.05$ & \multicolumn{2}{|c|}{$1.71 \pm 0.11$} & $1.24 \pm 0.11$ & $1.74 \pm 0.07$ & $1.17 \pm 0.04$ & $1.68 \pm 0.01$ \\
\hline & $\mathrm{COP}+\mathrm{A}+\mathrm{P}$ & $1.17 \pm 0.05$ & \multirow{2}{*}{\multicolumn{2}{|c|}{$\begin{array}{l}1.30 \pm 0.03 \\
1.19 \pm 0.15\end{array}$}} & $1.26 \pm 0.09$ & $1.21 \pm 0.03$ & $1.20 \pm 0.06$ & $1.23 \pm 0.07$ \\
\hline & Glass & $1.03 \pm 0.07$ & & & $1.06 \pm 0.12$ & $1.28 \pm 0.08$ & $1.20 \pm 0.09$ & $1.37 \pm 0.03$ \\
\hline
\end{tabular}

The values are mean of three individual vials. The error represents the standard deviation of the mean. COP, cyclic olefin polymer; A, absorber; $\mathrm{P}$, pouch; $\mathrm{m}$, month.

With regard to the polymer vials stored without any further packaging $(\mathrm{COP}-\mathrm{A}-\mathrm{P})$, we determined an increase in residual moisture for both formulations dependent on the storage temperature and time of observation. Within 12 months at $4{ }^{\circ} \mathrm{C}$, residual moisture content of LMU2 samples increased to $1.71 \% \pm 0.11 \%$. At elevated temperatures, i.e., $25^{\circ} \mathrm{C}$ and $40{ }^{\circ} \mathrm{C}$, residual moisture was $1.74 \% \pm 0.07 \%$ and $1.68 \% \pm 0.01 \%$ after 3 months for LMU2, respectively.

The smart packaging led to comparable changes in residual moisture over time as observed for the glass vials (Figure 4$)$. At refrigerated temperatures $\left(4^{\circ} \mathrm{C}\right)$ residual moisture content of COP $+\mathrm{A}+\mathrm{P}$ was $1.30 \% \pm 0.03 \%$ for $\mathrm{LMU} 2$ after 12 months (Figure $4 \mathrm{~A}$ ). Within 3 months at $25{ }^{\circ} \mathrm{C}$, residual moisture increased equally in COP $+\mathrm{A}+\mathrm{P}$ and glass for LMU1 $(0.81 \% \pm 0.02 \%$ and $0.68 \% \pm 0.02 \%$, respectively), whereas we observed constant moisture levels in the smart packaging for LMU2 $(1.21 \% \pm 0.03 \%)$ (Figure 4B). The same holds true for the samples stored at $40{ }^{\circ} \mathrm{C}$ over the course of 3 months; residual moisture content slightly increased to $0.84 \% \pm 0.01 \%$ in $\mathrm{COP}+\mathrm{A}+\mathrm{P}$ for $\mathrm{LMU} 1$, whereas it remained constant at $1.23 \% \pm 0.07 \%$ for LMU2 (Figure $4 \mathrm{C}$ ).
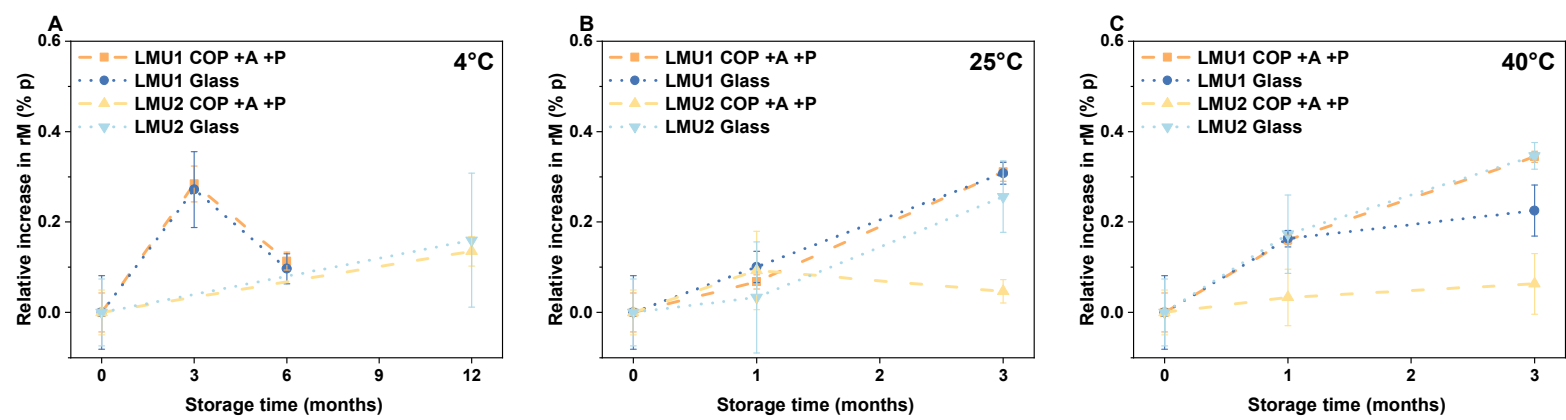

Figure 4. Relative changes in the residual moisture content of the lyophilizates in the smart packaging $(\mathrm{COP}+\mathrm{A}+\mathrm{P})$ and glass stored at (A) $4{ }^{\circ} \mathrm{C}$, (B) $25^{\circ} \mathrm{C}$ and (C) $40^{\circ} \mathrm{C}$ up to 6 months (LMU1) and 12 months (LMU2). Residual moisture content directly after lyophilization was set to $0 \% \mathrm{p}$ for all configurations. The values are means $(n=3) \pm$ standard deviation. COP, cyclic olefin polymer; $\mathrm{A}$, absorber; $\mathrm{P}$, pouch, $\% \mathrm{p}$, percentage point.

Similarly, we observed an increase in residual moisture for the glass vials depending on the storage temperature and time (Figure 4). After 12 months at $4{ }^{\circ} \mathrm{C}$, residual moisture 
content for LMU2 was $1.19 \% \pm 0.15 \%$ (Figure $4 \mathrm{~A}$ ) and at elevated temperatures, i.e., $25{ }^{\circ} \mathrm{C}$ and $40{ }^{\circ} \mathrm{C}, 1.28 \% \pm 0.08 \%$ and $1.37 \% \pm 0.03 \%$, respectively (Figure $4 \mathrm{~B}, \mathrm{C}$ ).

\subsection{Effect of the Smart Packaging on Protein Oxidation}

After lyophilization, we determined $6.25 \% \pm 0.08 \%$ (LMU1) and $5.60 \% \pm 0.03 \%$ (LMU2) of fully oxidized $\mathrm{mAb}$. When the COP vials were then stored at elevated storage temperatures without an absorber $(\mathrm{COP}-\mathrm{A}-\mathrm{P})$, an increase in oxidation by $0.59 \% \pm 0.11 \%$ for LMU1 and $0.14 \% \pm 0.12 \%$ for LMU2 was observed at $25^{\circ} \mathrm{C}$ after 3 months (Figure $5 \mathrm{~A}$ ). Furthermore, after 3 months at $40^{\circ} \mathrm{C}$, the percentage of fully oxidized mAb increased by $1.27 \% \pm 0.17 \%$ for LMU1 and $0.44 \% \pm 0.07 \%$ for LMU2, respectively (Figure $5 \mathrm{~B}$ ).
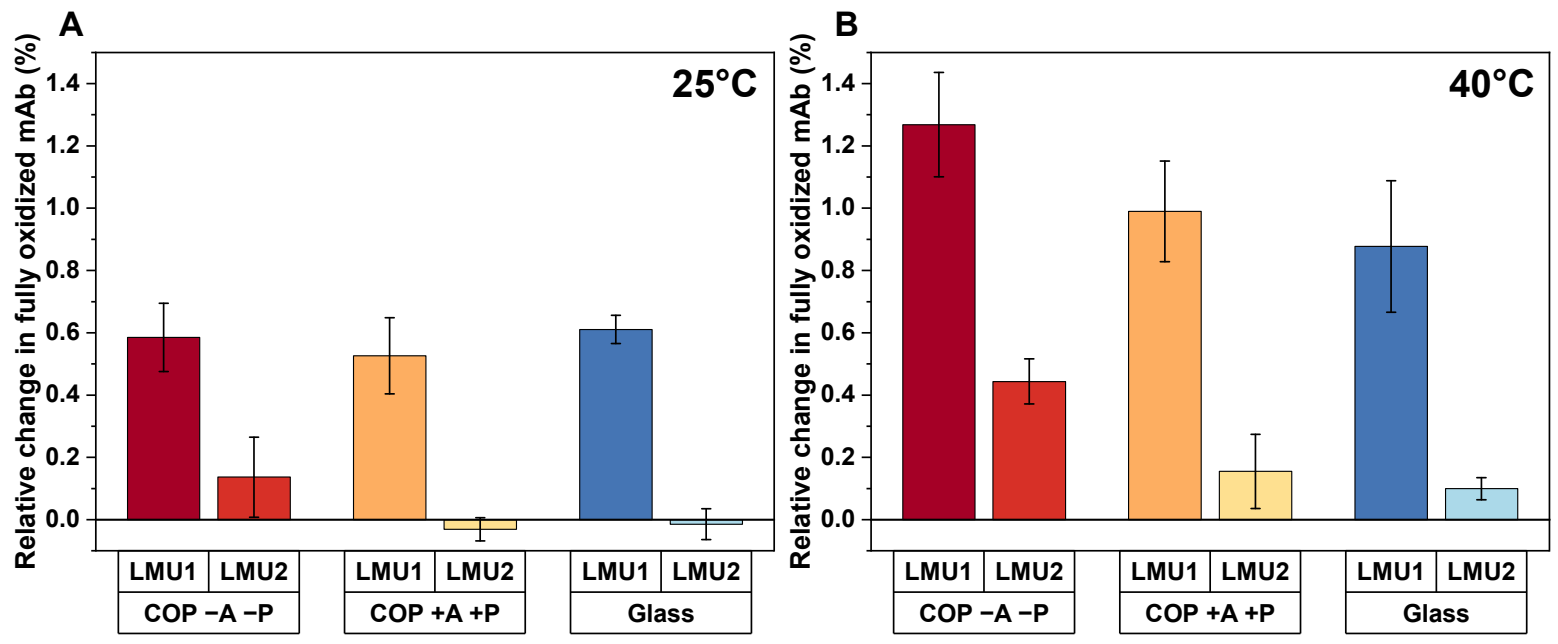

Figure 5. Relative change in fully oxidized $\mathrm{mAb}$ determined by hydrophobic interaction chromatography (HIC) for LMU1 and analytical protein A chromatography (PA) for LMU2 after 3 months of storage at $25^{\circ} \mathrm{C}(\mathrm{A})$ and $40^{\circ} \mathrm{C}(\mathbf{B})$. The bars are means $(n=3) \pm$ standard deviation. COP, cyclic olefin polymer; A, absorber; $\mathrm{P}$, pouch.

The smart packaging achieved similar amounts of oxidation in COP compared to glass. After storage at $25^{\circ} \mathrm{C}$ for 3 months, no significant change in the amount of fully oxidized LMU2 was found in COP $+\mathrm{A}+\mathrm{P}(-0.03 \% \pm 0.04 \%)$. Only a slight increase in oxidation was observed after 3 months of storage at $40^{\circ} \mathrm{C}$ for the respective antibody in the smart packaging $(0.16 \% \pm 0.12 \%)$. These overall changes within 3 months are comparable to the oxidation rates observed in glass $\left(-0.01 \% \pm 0.05 \%\right.$ at $25^{\circ} \mathrm{C}$ and $0.10 \% \pm 0.04 \%$ at $40{ }^{\circ} \mathrm{C}$ ). For LMU1, comparable changes in oxidation for the smart packaging and glass were found as well, even though the overall oxidation rate was increased for this antibody $(0.99 \% \pm 0.16 \%$ in $\mathrm{COP}+\mathrm{A}+\mathrm{P}$ and $0.88 \% \pm 0.21 \%$ in glass after 3 months storage at $40{ }^{\circ} \mathrm{C}$, respectively).

\subsection{Effect of the Vial Material on Particle Formation}

For both formulations subvisible particle counts (SvP) were detected with flow imaging microscopy (data not shown). All particle concentrations (given in \#/mL) are indicated cumulatively. Directly after lyophilization, particle counts for LMU1 of $24 \pm 14,221 \pm 123$ and $3014 \pm 748$ for $\geq 25 \mu \mathrm{m}, \geq 10 \mu \mathrm{m}$ and $\geq 1 \mu \mathrm{m}$ were found for COP, respectively. For the samples in glass vials, we determined $4 \pm 9,53 \pm 27$, and $2148 \pm 829$ for $\geq 25 \mu \mathrm{m}, \geq 10 \mu \mathrm{m}$, and $\geq 1 \mu \mathrm{m}$, respectively. After 6 months of storage at refrigerated temperatures counts for particles $\geq 25 \mu \mathrm{m}, \geq 10 \mu \mathrm{m}$ and $\geq 1 \mu \mathrm{m}$ were close to the initial amounts with $6 \pm 5$, $168 \pm 73$, and $2997 \pm 242$ for the smart packaging and $5 \pm 11,31 \pm 14$, and $990 \pm 103$ for glass, respectively. The same is true if the samples of LMU1 were stored at $40{ }^{\circ} \mathrm{C}$ for 3 months; flow imaging microscopy revealed $31 \pm 20,396 \pm 199$, and $4656 \pm 2172$ particles $\geq 25 \mu \mathrm{m}, \geq 10 \mu \mathrm{m}$, and $\geq 1 \mu \mathrm{m}$ for the smart packaging, and $4 \pm 6,60 \pm 39$, and $771 \pm 457$ for glass. We observed no significant difference regarding subvisible particles in the smart 
packaging versus COP $-\mathrm{A}-\mathrm{P}$ for LMU1 (53 \pm 51, $422 \pm 243$, and $4137 \pm 1831$ for particles $\geq 25 \mu \mathrm{m}, \geq 10 \mu \mathrm{m}$, and $\geq 1 \mu \mathrm{m}$ ) as well as for LMU2 after storage at $40{ }^{\circ} \mathrm{C}$ for 3 months.

Initially, particle counts for LMU2 after lyophilization were $31 \pm 18,2941 \pm 911$, and $20172 \pm 4225$ for particles $\geq 25 \mu \mathrm{m}, \geq 10 \mu \mathrm{m}$, and $\geq 1 \mu \mathrm{m}$ for the smart packaging. In the glass vials we found $1 \pm 3,30 \pm 18$, and $465 \pm 252$ particles $\geq 25 \mu \mathrm{m}, \geq 10 \mu \mathrm{m}$, and $\geq 1 \mu \mathrm{m}$, respectively. After storage at $4{ }^{\circ} \mathrm{C}$ for 12 months, subvisible particle counts in $\mathrm{COP}+\mathrm{A}$ $+\mathrm{P}$ decreased to $28 \pm 11,279 \pm 33$, and $4598 \pm 824$ for the aforementioned particle sizes. Similarly, particle numbers in the smart packaging decreased after 3 months of storage at $40{ }^{\circ} \mathrm{C}(32 \pm 17,291 \pm 100$, and $7376 \pm 2324$ for particles $\geq 25 \mu \mathrm{m}, \geq 10 \mu \mathrm{m}$, and $\geq 1 \mu \mathrm{m})$. No pronounced change in SvP was seen in glass vials after 3 months at $40{ }^{\circ} \mathrm{C}(15 \pm 14$, $48 \pm 14,456 \pm 107$, respectively).

\section{Discussion}

The aim of our study was to demonstrate that an appropriate secondary packaging for lyophilizates in COP vials provides constantly low oxygen and residual moisture levels. Consequently, protein oxidation in the primary container is comparable to glass vials due to the oxygen and moisture removing capability of an absorber in the package.

After sealing of the aluminum pouches, oxygen from the enclosed air was rapidly removed by the absorber (Figure 2). With a concentration of less than $0.3 \%$ remaining oxygen, the cavity in the secondary packaging was practically deoxygenated. Moreover, we found unchangingly low oxygen levels in the pouch stored at $4{ }^{\circ} \mathrm{C}$ for one year, proving sealed aluminum pouches hold perfectly tight as well as the absorber's long-lasting capability in removing oxygen. Hence, we think that there is no need for sealing the pouches under inert gases, which in turn increases production costs.

The amount of oxygen in the headspaces of the lyophilizates stored in COP vials without any further secondary packaging increased rapidly, as expected (Figure 3). Due to the permeability of plastics to gases, Qadry et al. found a half-life duration of 15 days for oxygen to increase to $9.4 \%$ in CZ-resin COP vials [32]. Thus, less barrier properties to gases compared to glass as one of the major drawbacks of polymer vials was confirmed [10]. However, this supposed detriment was already successfully employed to advantage for liquid protein formulations, since dissolved oxygen was removed from polymer-based syringes by a deoxygenated packaging system and therefore oxidation could be prevented $[25,26]$. However, in the present study, we were not able to rapidly remove oxygen from the vials containing lyophilizates. Since the surrounding air in the pouch was successfully deoxygenated for the smart packaging, no further oxygen permeated into the vials and we observed constantly low oxygen amounts in the headspaces of $\mathrm{COP}+\mathrm{A}+\mathrm{P}$, similar to glass. Compared to Nakamura et al., who observed no dissolved oxygen remaining in their liquid formulation in a COP syringe after 56 days in the deoxygenated packaging system [25], removal of oxygen seems to be less effective when it comes to lyophilized, i.e., solid formulations, enclosed in a vial. Of course, storage time and temperature have an effect on the diffusive exchange of gaseous oxygen from the lyophilizates, and we determined slightly lower oxygen amounts in the headspaces after storage for one year at $4{ }^{\circ} \mathrm{C}$ (Figure 3A) and at elevated temperatures compared to glass (Figure 3B,C). Nevertheless, an actual strong, practically relevant removal of oxygen from COP was not possible, and we are further evaluating the situation.

Remarkably homogeneous heat transfer was reported for polymeric vials during lyophilization, although the thermal conductivity is lower for COP $\left(\sim 0.2 \mathrm{~W} \mathrm{~m}^{-1} \mathrm{~K}^{-1}\right)$ compared to glass $\left(\sim 1.05 \mathrm{~W} \mathrm{~m}^{-1} \mathrm{~K}^{-1}\right)[18,33]$. This leads to slightly higher initial residual moisture contents in COP compared to glass because less energy is transferred into the COP vial (Table 1). As with oxygen, COP is permeable to water vapor $[9,34]$. Consequently, residual moisture significantly increased over time in COP $-\mathrm{A}-\mathrm{P}$ due to the lack of a sufficient barrier. In contrast to that, residual moisture levels in the smart packaging (COP $+\mathrm{A}+\mathrm{P}$ ) only slightly increased over the course of 6 (LMU1) and 12 months (LMU2) of storage at $4{ }^{\circ} \mathrm{C}$, very similarly to glass (Figure $4 \mathrm{~A}$ ). Such a slight increase is frequently observed in 
lyophilizates, and equilibrium moisture level depends on product characteristics according to Pikal et al. [35]. Moreover, regarding the residual moisture content at elevated storage temperatures, i.e., $25{ }^{\circ} \mathrm{C}$ and $40{ }^{\circ} \mathrm{C}$, we again found very similar levels in the smart packaging compared to glass due to the dry air in the pouch (Figure $4 \mathrm{~B}, \mathrm{C}$ ). Accordingly, the moisture-absorbing capability is a useful synergistic effect when it comes to lyophilizates, since long-term protein stability generally decreases with increasing moisture content [23]. For LMU2, we even observed constant residual moisture levels in $\mathrm{COP}+\mathrm{A}+\mathrm{P}$ over storage and no increase over time at all. The possibility to remove moisture from lyophilizates in $\mathrm{COP}$ vials remains an option and needs to be studied with regard to different container stoppers (i.e., different brands, polymers, pretreatments, etc.).

Although chemical reactions are decelerated in lyophilizates because of the low water content, proteins undergo oxidation in the dried state as well [20,36]. In our study, we examined two clinically relevant antibodies to evaluate the actual profit of our smart packaging. One strategy to reduce oxidation is to reduce or exclude oxygen [37]. Hence, as a consequence of the consistently low and comparable headspace oxygen levels in COP $+\mathrm{A}+\mathrm{P}$ and glass we found similar amounts of oxidation in both packaging configurations irrespective of the storage temperature (Figure 5). Furthermore, with increasing levels of oxygen in the headspace ( $\mathrm{COP}-\mathrm{A}-\mathrm{P}$ ) the amount of fully oxidized $\mathrm{mAb}$ increases for both antibodies. Although the absolute changes in oxidation may appear low to moderate at first glance, more pronounced effects may be achieved in other, oxidation-sensitive systems. Note that the examined mAbs were already oxidized to a certain extend right from the start. Since protein oxidation is one of the major degradation pathways leading to altered conformation and biological activity $[19,21]$, suppression of this degradation pathway is of utmost interest. Nevertheless, there is no superiority of $\mathrm{COP}+\mathrm{A}+\mathrm{P}$ over glass for the lyophilizates. With regard to the comparable headspace oxygen levels of the two configurations, similar degrees of oxidation are expectable.

Apart from chemical degradation, physical instabilities are also of relevance. As proteins are naturally interacting with surfaces, container materials have to be carefully selected $[9,38,39]$. We found low particle amounts for LMU1 throughout the study irrespective of the configuration, although subvisible particles $\geq 10 \mu \mathrm{m}$ and $\geq 1 \mu \mathrm{m}$ were slightly higher in COP compared to glass. Unexpectedly, subvisible particles of the order of $\geq 10 \mu \mathrm{m}$ and $\geq 1 \mu \mathrm{m}$ were found to be increased in COP directly after freeze-drying for LMU2. Particle counts then decreased over the course of 12 months at $4{ }^{\circ} \mathrm{C}$ to one fourth as well as within 3 months at $40^{\circ} \mathrm{C}$ to one third of the starting value for particles $\geq 1 \mu \mathrm{m}$, respectively. Nevertheless, in general we observe low cumulative particle amounts for both $\mathrm{mAbs}$ after storage for 3 months even at elevated temperatures (i.e., $25^{\circ} \mathrm{C}$ and $40^{\circ} \mathrm{C}$ ). More recently, it has been reported that protein adsorption to cyclic olefin polymer is scarcely observed $[12,13,40,41]$ and if so, it is mainly caused by the hydrophobic effect [42]. We assume that interaction of LMU2 with the hydrophobic surface of COP is the driving force for the increased subvisible particle counts after lyophilization since the mAb exhibits high hydrophobicity.

\section{Conclusions}

In conclusion, we presented a packaging approach for lyophilizates in COP vials (i.e., "smart packaging"), which disposes of permeability issues and renders stable, low headspace oxygen and residual moisture levels due to a combined oxygen and moisture absorber. Consequently, oxidation of two therapeutic monoclonal antibodies was found to be comparable to glass vials. Thus, the major drawback of cyclic olefin polymers regarding the use in the field of freeze-drying has been overcome. Possible concerns with respect to the suitability of cyclic olefin materials for lyophilization (e.g., conductivity issues) can be dispelled. Moreover, a low particle burden was observed after storage at elevated temperatures. The exceptional advantages of the smart packaging, such as the durable and inert polymer material, the tamper-evident closure of the pouch, as well as protection from light and cushioning against mechanical shock in the package optimally preserve sensitive 
biotech drugs. The numerous benefits of the packaging outweigh potential additional costs by far, particularly since to date secondary packaging of costly biopharmaceuticals is widely disregarded. Nevertheless, a drastic reduction of oxygen in the COP vials as seen for prefilled syringes $[25,26]$ was not achieved. Further studies are needed to understand why the capability in removing oxygen from lyophilizates differs from liquid formulations in deoxygenated packaging concepts.

Supplementary Materials: The following are available online at https://www.mdpi.com/article/ 10.3390/pharmaceutics13101695/s1, Figure S1: MAbPac HIC-20, 5 m, $4.6 \times 250$ mm calibration data. (A) Hydrophobic interaction chromatography (HIC) chromatograms of the initial material and artificially oxidized $\mathrm{mAb}$ as well as the respective mixtures. (B) Percentage of fully oxidized $\mathrm{mAb}$ was determined experimentally and plotted against the theoretical amount of fully oxidized species. Calibration was performed in a linear range between $5 \%$ and $50 \%$ oxidized $\mathrm{mAb}$ residues. $75 \%$ and $100 \%$ were excluded. Figure S2: POROS ${ }^{A} A, 20 \mu \mathrm{m}, 4.6 \times 50 \mathrm{~mm}$ calibration data. (A) Protein A chromatography chromatograms of the initial material and artificially oxidized $\mathrm{mAb}$ as well as the respective mixtures. (B) Percentage of fully oxidized $\mathrm{mAb}$ was determined experimentally and plotted against the theoretical amount of fully oxidized species. Calibration was performed in a linear range between $5 \%$ and $100 \%$ oxidized mAb residues.

Author Contributions: Conceptualization, G.W.; methodology, N.H., T.M., and G.W.; formal analysis, N.H. and T.M.; investigation, N.H.; resources, G.W.; data curation, N.H., T.M.; writing-original draft preparation, N.H.; writing-review and editing, T.M. and G.W.; visualization, N.H.; supervision, T.M. and G.W.; project administration, G.W.; funding acquisition, G.W. All authors have read and agreed to the published version of the manuscript.

Funding: This research received no external funding.

Institutional Review Board Statement: Not applicable.

Informed Consent Statement: Not applicable.

Data Availability Statement: Data are contained within the article.

Acknowledgments: We thank Gerresheimer AG for providing the COP Monolayer vials.

Conflicts of Interest: The authors declare no conflict of interest. T.M. is Chief Technology Officer at Coriolis Pharma, and Coriolis pharma had no role in the design of the study; in the collection, analyses, or interpretation of the data; in the writing of the manuscript; or in the decision to publish the results.

\section{References}

1. BiopharmaDealmakers Moving up with the Monoclonals. Available online: https://www.nature.com/articles/d43747-020-007 65-2 (accessed on 15 August 2021).

2. Uchiyama, S. Liquid formulation for antibody drugs. Biochim. Biophys. Acta Proteins Proteom. 2014, 1844, 2041-2052. [CrossRef] [PubMed]

3. Mahler, H.-C.; Müller, R.; Frie $\beta$, W.; Delille, A.; Matheus, S. Induction and analysis of aggregates in a liquid IgG1-antibody formulation. Eur. J. Pharm. Biopharm. 2005, 59, 407-417. [CrossRef]

4. Gervasi, V.; Dall Agnol, R.; Cullen, S.; McCoy, T.; Vucen, S.; Crean, A. Parenteral protein formulations: An overview of approved products within the European Union. Eur. J. Pharm. Biopharm. 2018, 131, 8-24. [CrossRef] [PubMed]

5. Tang, X.; Pikal, M.J. Design of Freeze-Drying Processes for Pharmaceuticals: Practical Advice. Pharm. Res. 2004, 21, 191-200. [CrossRef] [PubMed]

6. Carpenter, J.F.; Pikal, M.J.; Chang, B.S.; Randolph, T.W. Rational Design of Stable Lyophilized Protein Formulations: Some Practical Advice. Pharm. Res. 1997, 14, 969-975. [CrossRef] [PubMed]

7. Sacha, G.A.; Saffell-Clemmer, W.; Abram, K.; Akers, M.J. Practical fundamentals of glass, rubber, and plastic sterile packaging systems. Pharm. Dev. Technol. 2010, 15, 6-34. [CrossRef] [PubMed]

8. Dietrich, C.; Maurer, F.; Roehl, H.; Frieß, W.; Maurer, F.; Roehl, H.; Frieß, W. Pharmaceutical Packaging for Lyophilization Applications. In Freeze-Drying/Lyophilization of Pharmaceutical and Biological Products; Rey, L., Ed.; CRC Press: Boca Raton, FL, USA, 2010; pp. 283-395.

9. Waxman, L.; DeGrazio, F.L.; Vilivalam, V.D. Plastic packaging for parenteral drug delivery. In Parenteral Medications, 4th ed.; CRC Press: Boca Raton, FL, USA, 2019; pp. 479-510, ISBN 9780429201400. 
10. Yoneda, S.; Torisu, T.; Uchiyama, S. Development of syringes and vials for delivery of biologics: Current challenges and innovative solutions. Expert Opin. Drug Deliv. 2021, 18, 459-470. [CrossRef]

11. Breakage and Particle Problems in Glass Vials and Syringes Spurring Industry Interest in Plastics. Available online: https:/ / www.ipqpubs.com/2011/08/07/breakage-and-particle-problems-in-glass-vials-and-syringes-spurring-industryinterest-in-plastics / (accessed on 8 August 2021).

12. Qadry, S.S.; Roshdy, T.H.; Char, H.; Del Terzo, S.; Tarantino, R.; Moschera, J. Evaluation of CZ-resin vials for packaging protein-based parenteral formulations. Int. J. Pharm. 2003, 252, 207-212. [CrossRef]

13. Mathes, J.; Friess, W. Influence of $\mathrm{pH}$ and ionic strength on IgG adsorption to vials. Eur. J. Pharm. Biopharm. 2011, 78, 239-247. [CrossRef] [PubMed]

14. Lee, M.; Keener, J.; Rodgers, G.M.; Adachi, R.Y. Novel polymer container systems for protein therapeutics and cell culturing. Int. J. Polym. Mater. Polym. Biomater. 2016, 65, 568-573. [CrossRef]

15. Kraft, C.; Glen, K.E.; Harriman, J.; Thomas, R.; Lyness, A.M. Evaluation of a novel cyclic olefin polymer container system for cryopreservation of adeno-associated virus. Cytotherapy 2020, 22, S147-S148. [CrossRef]

16. Lyness, A.M.; Kraft, C.; Hashimdeen, S.; Rafiq, Q.A. Comparison of rigid polymer vials and flexible bags for cryopreservation of T cells. Cytotherapy 2020, 22, S148. [CrossRef]

17. Belboom, S.; Renzoni, R.; Verjans, B.; Léonard, A.; Germain, A. A life cycle assessment of injectable drug primary packaging: Comparing the traditional process in glass vials with the closed vial technology (polymer vials). Int. J. Life Cycle Assess. 2011, 16, 159-167. [CrossRef]

18. Hibler, S.; Wagner, C.; Gieseler, H. Vial Freeze-Drying, part 1: New Insights into Heat Transfer Characteristics of Tubing and Molded Vials. J. Pharm. Sci. 2012, 101, 1189-1201. [CrossRef] [PubMed]

19. Cleland, J.L.; Powell, M.F.; Shire, S.J. The development of stable protein formulations: A close look at protein aggregation, deamidation, and oxidation. Crit. Rev. Ther. Drug Carrier Syst. 1993, 10, 307-377.

20. Li, S.; Schöneich, C.; Borchardt, R.T. Chemical instability of protein pharmaceuticals: Mechanisms of oxidation and strategies for stabilization. Biotechnol. Bioeng. 1995, 48, 490-500. [CrossRef] [PubMed]

21. Torosantucci, R.; Schöneich, C.; Jiskoot, W. Oxidation of Therapeutic Proteins and Peptides: Structural and Biological Consequences. Pharm. Res. 2014, 31, 541-553. [CrossRef] [PubMed]

22. Shalaev, E.Y.; Zografi, G. How Does Residual Water Affect the Solid-state Degradation of Drugs in the Amorphous State? J. Pharm. Sci. 1996, 85, 1137-1141. [CrossRef]

23. Wang, W. Lyophilization and development of solid protein pharmaceuticals. Int. J. Pharm. 2000, 203, 1-60. [CrossRef]

24. Oksanen, C.A.; Zografi, G. The Relationship Between the Glass Transition Temperature and Water Vapor Absorption by Poly(vinylpyrrolidone). Pharm. Res. 1990, 7, 654-657. [CrossRef] [PubMed]

25. Nakamura, K.; Abe, Y.; Kiminami, H.; Yamashita, A.; Iwasaki, K.; Suzuki, S.; Yoshino, K.; Dierick, W.; Constable, K. A Strategy for the Prevention of Protein Oxidation by Drug Product in Polymer-Based Syringes. PDA J. Pharm. Sci. Technol. 2015, 69, 88-95. [CrossRef]

26. Masato, A.; Kiichi, F.; Uchiyama, S. Suppression of Methionine Oxidation of a Pharmaceutical Antibody Stored in a Polymer-Based Syringe. J. Pharm. Sci. 2016, 105, 623-629. [CrossRef]

27. Werner, B.P.; Schöneich, C.; Winter, G. Silicone Oil-Free Polymer Syringes for the Storage of Therapeutic Proteins. J. Pharm. Sci. 2019, 108, 1148-1160. [CrossRef] [PubMed]

28. Svilenov, H.; Gentiluomo, L.; Friess, W.; Roessner, D.; Winter, G. A New Approach to Study the Physical Stability of Monoclonal Antibody Formulations-Dilution From a Denaturant. J. Pharm. Sci. 2018, 107, 3007-3013. [CrossRef]

29. Baek, J.; Liu, X. Separation of Monoclonal Antibody (mAb) Oxidation Variants on a High-Resolution HIC Column; Thermo Fisher Scientific: Sunnyvale, CA, USA, 2020. Available online: https://tools.thermofisher.com/content/sfs/brochures/AN-21069-LCMAbPac-HIC-20-Oxidized-mAb-Separation-AN21069-EN.pdf (accessed on 27 March 2020).

30. Yang, H.; Koza, S.; Chen, W. Anion-Exchange Chromatography for Determining Empty and Full Capsid Contents in Adeno-Associated Virus; Waters Corporation: Milford, MA, USA, 2019. Available online: https://www.waters.com/content/dam/waters/en/appnotes / 2020/720006825/720006825-zh.pdf (accessed on 26 November 2020).

31. Loew, C.; Knoblich, C.; Fichtl, J.; Alt, N.; Diepold, K.; Bulau, P.; Goldbach, P.; Adler, M.; Mahler, H.-C.; Grauschopf, U. Analytical Protein A Chromatography as a Quantitative Tool for the Screening of Methionine Oxidation in Monoclonal Antibodies. J. Pharm. Sci. 2012, 101, 4248-4257. [CrossRef] [PubMed]

32. Qadry, S.; Roshdy, T.; Knox, D.; Phillips, E. Model development for $\mathrm{O}_{2}$ and $\mathrm{N}_{2}$ permeation rates through CZ-resin vials. Int. J. Pharm. 1999, 188, 173-179. [CrossRef]

33. McAndrew, T.P.; Hostetler, D.; DeGrazio, F.L. Container and Reconstitution Systems for Lyophilized Drug Products. In Lyophilization of Pharmaceuticals and Biologicals: New Technologies and Approaches; Ward, K.R., Matejtschuk, P., Eds.; Springer: New York, NY, USA, 2019; pp. 193-214, ISBN 978-1-4939-8928-7.

34. Presser, I. Innovative Online Messverfahren zur Optimierung von Gefriertrocknungsprozessen. Dissertation zur Erlangung des Doktorgrades, Fakultät für Chemie und Pharmazie, Ludwig-Maximilians-Universität München, München, Germany, 2003.

35. Pikal, M.J.; Shah, S. Moisture transfer from stopper to product and resulting stability implications. Dev. Biol. Stand. 1992, 74, 165-177. [PubMed] 
36. Kenkare, U.W.; Richards, F.M. The histidyl residues in ribonuclease-S. Photooxidation in solution and in single crystals; the iodination of histidine-12. J. Biol. Chem. 1966, 241, 3197-3206. [CrossRef]

37. Fujimoto, S.; Nakagawa, T.; Ishimitsu, S.; Ohara, A. On the Mechanism of Inactivation of Papain by Bisulfite. Chem. Pharm. Bull. 1983, 31, 992-1000. [CrossRef] [PubMed]

38. Mahler, H.-C.; Friess, W.; Grauschopf, U.; Kiese, S. Protein aggregation: Pathways, induction factors and analysis. J. Pharm. Sci. 2009, 98, 2909-2934. [CrossRef]

39. Perevozchikova, T.; Nanda, H.; Nesta, D.P.; Roberts, C.J. Protein adsorption, desorption, and aggregation mediated by solid-liquid interfaces. J. Pharm. Sci. 2015, 104, 1946-1959. [CrossRef] [PubMed]

40. Fujita, R.; Nagatoishi, S.; Adachi, S.; Nishioka, H.; Ninomiya, H.; Kaya, T.; Takai, M.; Arakawa, T.; Tsumoto, K. Control of Protein Adsorption to Cyclo Olefin Polymer by the Hofmeister Effect. J. Pharm. Sci. 2019, 108, 1686-1691. [CrossRef] [PubMed]

41. Eu, B.; Cairns, A.; Ding, G.; Cao, X.; Wen, Z.-Q. Direct Visualization of Protein Adsorption to Primary Containers by Gold Nanoparticles. J. Pharm. Sci. 2011, 100, 1663-1670. [CrossRef] [PubMed]

42. Yoneda, S.; Maruno, T.; Mori, A.; Hioki, A.; Nishiumi, H.; Okada, R.; Murakami, M.; Zekun, W.; Fukuhara, A.; Itagaki, N.; et al. Influence of protein adsorption on aggregation in prefilled syringes. J. Pharm. Sci. 2021. [CrossRef] [PubMed] 